\title{
Plant density and nitrogen topdressing of high-altitude main-season corn
}

\section{Densidade de plantas e doses de nitrogênio em cobertura no milho safra em elevada altitude}

\author{
Denis Piazzoli'; Moryb Jorge Lima da Costa Sapucay²*; André Mateus Prando3; \\ João Alberto de Oliveira Júnior ${ }^{4}$; Claudemir Zucareli ${ }^{5}$
}

\section{Highlights}

Corn is influenced by the interaction between plant density and $\mathrm{N}$ rates.

Under high-altitude edaphoclimatic conditions the maximum yield is $15.6 \mathrm{Mg} \mathrm{ha}^{-1}$.

Maximum yield was recorded at 105,000 plants ha-1 and $185 \mathrm{~kg} \mathrm{ha}^{-1}$ of $\mathrm{N}$.

Maximum height was recorded at 75,000 plants ha-1 and $169 \mathrm{~kg} \mathrm{ha}^{-1}$ of $\mathrm{N}$.

$\mathrm{N}$ attenuates the reduction in stem diameter resulting from increased plant density.

\section{Abstract}

An appropriate combination of plant density with nitrogen $(\mathrm{N})$ fertilization can optimize corn growth and increase grain yields. This study evaluated the effects of nitrogen topdressing rates and plant density levels on the agronomic performance of corn. The early hybrid DKB 240 YG, with high yield potential and stability, was evaluated in two summer crops in Mauá da Serra, Paraná (950 m asl), in a Cfb climate, on a Rhodic Eutrudox. The experiment was arranged in randomized complete blocks and subdivided plots with four replications. The plant densities $(60,000 ; 75,000 ; 90,000$ and 105,000 plants ha-1) were assessed in the plots and the nitrogen (ammonium nitrate 32\% N) topdressing rates $\left(0,60,120,180\right.$ and $240 \mathrm{~kg} \mathrm{ha}^{-1}$ ) in the subplots. The stem diameter, plant height, ear insertion height and grain yield were evaluated. The stem diameter, plant height, ear insertion height and grain yield were influenced by the interaction between plant density and nitrogen topdressing under the tested high-altitude edaphoclimatic conditions. The stem diameter of corn plants decreased due to the increase in plant density whereas nitrogen topdressing attenuated this reduction. Maximum plant height was observed at a density of 75,000 plants ha-1 associated with a topdressing of $169 \mathrm{~kg} \mathrm{ha}^{-1}$ of $\mathrm{N}$, and highest ear insertion at 60,000 plants ha-1 and $168 \mathrm{~kg} \mathrm{ha}^{-1}$ of $\mathrm{N}$.

1 Technical Manager, Bayer of Brazil, São Paulo, SP, Brazil. E-mail: denis.piazzoli@bayer.com

2 Doctorate in Agronomy, Center for Agricultural Sciences, Universidade Estadual de Londrina, UEL, Londrina, PR, Brazil. E-mail: moryb_sapucay@hotmail.com

${ }^{3}$ Researcher, Empresa Brasileira de Pesquisa Agropecuária, EMBRAPA Soja, Londrina, PR, Brazil. E-mail: andre. prando@embrapa.br

${ }^{4}$ Innovation Director, Agricultura Inteligente, Ag. In., Uberlândia, MG, Brazil. E-mail: joao.oliveira@agin.agr.br

5 Prof. Dr., Department of Agronomy, Center for Agricultural Sciences, UEL, Londrina, PR, Brazil. E-mail: claudemircca@ uel.br

* Author for correspondence

Received: Aug. 07, 2020 - Approved: May 14, 2021 
Corn yield was highest at a density of 105,000 plants ha-1 associated with a topdressing of $185 \mathrm{~kg} \mathrm{~N}^{-1}$ of $\mathrm{N}$.

Key words: Nitrogen fertilization. Plant population. Zea mays L.

\section{Resumo}

A adequada combinação entre densidade de plantas e adubação nitrogenada $(\mathrm{N})$ pode favorecer $\mathrm{O}$ crescimento e incrementar a produtividade de grãos do milho. Objetivou-se avaliar o efeito de níveis da adubação nitrogenada em cobertura associado a densidades de plantas sobre o desempenho agronômico do milho. O experimento foi conduzido em duas safras de verão em Mauá da Serra - PR (950 m), clima do tipo $\mathrm{Cfb}$, em Latossolo Vermelho distroférrico, com o híbrido precoce de alto potencial produtivo e estabilidade no plantio DKB 240 YG. Utilizou-se blocos completos casualizados e parcelas subdivididas, com quatro repetições. Nas parcelas, alocaram-se as densidades de plantas $(60.000,75.000,90.000 \mathrm{e}$ 105.000 plantas ha-1 $^{-1}$ ) e, nas subparcelas, as doses de $\mathrm{N}$ (nitrato de amônio $32 \% \mathrm{~N}$ ) em cobertura $(0,60,120$, 180 e $240 \mathrm{~kg} \mathrm{ha}^{-1}$ ). Foram avaliados o diâmetro de colmo, a altura de plantas e de inserção da espiga e a produtividade de grãos. O diâmetro do colmo, a altura de plantas, de inserção da espiga e a produtividade de grãos são influenciadas pela interação entre densidade de plantas e níveis de $\mathrm{N}$ em cobertura sob condições edáficas e meteorológicas em elevada altitude. O diâmetro de colmo do milho diminui pelo acréscimo na densidade de plantas e o $\mathrm{N}$ em cobertura atenua essa redução. A altura máxima das plantas foi observada na densidade de 75.000 plantas ha-1 associada a cobertura de $169 \mathrm{~kg} \mathrm{ha}^{-1}$ de $\mathrm{N}$ e a maior inserção de espigas com 60.000 plantas ha-1 e $168 \mathrm{~kg} \mathrm{ha}^{-1}$ de $\mathrm{N}$. A produtividade do milho foi maior na densidade de 105.000 plantas ha-1 associada a uma cobertura de $185 \mathrm{~kg} \mathrm{ha}^{-1}$ de $\mathrm{N}$.

Palavras-chave: Adubação nitrogenada. População de plantas. Zea mays L.

\section{Introduction}

Corn (Zea mays L.) is the most widely produced and consumed cereal in the world and in this scenario, Brazil is one of the largest producers (United States Department of Agriculture [USDA], 2020). In Brazil, secondseason corn ranks first in area and production, but main-season corn is extremely important in regions where the conditions of solar radiation, temperature and humidity in autumn-winter make late cropping unfeasible. Although corn yield has increased in recent decades due to factors related to breeding and improved crop management (Schwalbert et al., 2018), yields can be raised even further. The optimization of management practices such as plant density and nitrogen fertilization are essential to improve corn yields.

The spatial arrangement was adapted to raise the plant density in the planting rows with a view to determining the ideal density for maximized corn grain yields, with an optimized use of resources such as water, light and nutrients (Abuzar et al., 2011). In relation to the ideal density, low plant densities lead to underutilization of resources, while very high densities increase intraspecific competition and can reduce the photosynthetic activity and partitioning of photoassimilates for grain production, decreasing the cereal yield (Sangoi et al., 2019). 
Another important factor to maximize corn yield is the crop nutritional management. Nitrogen is the nutrient with the highest requirements for crop growthand development and induces the strongest response in yield gain, as long as other factors such as solar radiation, temperature and humidity are not limiting (Al-Naggar, Shabana, Atta, \& Al-Khalil, 2015).

In a study of Cruz, Garcia, Pereira, Pinto and Queiroz (2009), with data of 1,095 mainseason corn crops, all with yields above 8,000 $\mathrm{kg} \mathrm{ha}^{-1}$, plant densities between 40 and 84,000 plants ha-1 were found. While $65 \%$ of the producers planted more than 65,000 plants per hectare, about $30 \%$ used a density of more than 70,000 plants $\mathrm{ha}^{-1}$. The mean nitrogen topdressing for yields up to $8-10 \mathrm{Mg} \mathrm{ha}^{-1}$ was $108 \mathrm{~kg} \mathrm{ha}^{-1}$ of $\mathrm{N}$, for yields up to $10-12 \mathrm{Mg} \mathrm{ha}^{-1}$ the mean topdressing was $125 \mathrm{~kg} \mathrm{ha}^{-1}$ of $\mathrm{N}$ and for yields above $12 \mathrm{Mg} \mathrm{ha}^{-1}$ a topdressing of $136 \mathrm{~kg} \mathrm{ha}^{-1}$ of $\mathrm{N}$ was applied.

The intensification of production systems, for which cultivation windows (fallow periods) have to be better exploited, has required the adaptation of cultivars. Corn breeding programs have introduced genetic, physiological and morphological modifications to improve the use of natural resources and tolerance to environmental stresses (Tokatlidis et al., 2011; Gong, Wu, Zhang, Chen, \& Wang, 2015). The modern, high-yielding hybrids can tolerate high plant densities, due to characteristics such as a more compact architecture and greater responsiveness to $\mathrm{N}$ fertilization (Modolo, Carnieletto, Kolling, Trogello, \& Sgarbossa, 2010; Ciampitti \& Vyn, 2012).

A higher plant density associated with the adaptation of the amount of $\mathrm{N}$ to supply the higher requirement of densely planted corn can maximize cereal yields (Mendes et al., 2013; Al-Naggar et al., 2015). The responses are however rather variable (Schwalbert et al., 2018; Ciampitti \& Vyn, 2012), since the density indicated for optimized yields is influenced by several factors, e.g., altitude, longitude, soil type and fertility, water availability, luminosity, genotype and fertilization levels (Silva et al., 2010).

Thus, environmental aspects of each production site in each growing season must be taken into account to make recommendations for corn cultivation more region-specific and less generalized, to improve the agronomic performance and yield response of the crop (Neumann, Poczynek, Leão, Figueira, \& Souza, 2018). In the state of Paraná, the recommendation for corn nitrogen fertilization is to take the fertilization of the previous crop and the expected yield into consideration (Pauletti \& Motta, 2019).

The development of higher-yielding cultivars that are more responsive to higher $\mathrm{N}$ fertilization and plant densities requires the evaluation of combinations of these factors to be able to explore the genetic potential of corn in high altitude environments. In this context, the objective was to evaluate the effects of nitrogen topdressing rates and plant density levels on the agronomic performance of corn.

\section{Material and Methods}

The experiment was carried out in Mauá da Serra - PR $\left(23^{\circ} 84^{\prime} \mathrm{S}, 5^{\circ} 23^{\prime} \mathrm{W}\right.$; 950 $\mathrm{m}$ asl), in two consecutive summer growing seasons. The soil of the experimental area was characterized as Latossolo Vermelho Distroférrico (Santos et al., 2018) or Rhodic 
Eutrudox (USDA 2014). According to the Köppen classification, the regional climate is temperate $(\mathrm{Cfb})$ and the average temperature in the coldest month is below $18^{\circ} \mathrm{C}$, summers are cool, the average temperature in the hottest month is below $22^{\circ} \mathrm{C}$ and there is no clearly defined dry season. Meteorological data (rainfall and temperature) are shown in Figure 1.

The experiment was arranged in a complete randomized block design with split-plots and four replications. The plant populations $(60,000 ; 75,000 ; 90,000$; and 105,000 plants ha $^{-1}$ ) were allocated in the plots and the $\mathrm{N}$ topdressing rates $(0,60,120$, 180 and $\left.240 \mathrm{~kg} \mathrm{ha}^{-1}\right)$, using ammonium nitrate $(32 \% N)$, in the subplots. The experimental unit consisted of six 5-m rows, with an inter-row spacing of $0.7 \mathrm{~m}$, of which the central rows were evaluated.

The experiment was run at the same location in both growing seasons. Prior to the planting of the experiment, the soil $(0-0.2$ $\mathrm{m}$ layer) was sampled and analyzed, with the following results: growing season 1: $5.5 \mathrm{pH}$ $\left(\mathrm{CaCl}_{2}\right) ; 8.5 \mathrm{mg} \mathrm{dm}^{-3} \mathrm{P}$ (Mehlich-1); $38 \mathrm{~g} \mathrm{~kg}^{-1}$ $\mathrm{OM} ; 0.0 \mathrm{cmol}_{\mathrm{c}} \mathrm{dm}^{-3} \mathrm{Al}^{3+} ; 5.6 \mathrm{cmol}_{\mathrm{c}} \mathrm{dm}^{-3} \mathrm{H}+\mathrm{Al}$; $0.36 \mathrm{cmol}_{\mathrm{c}} \mathrm{dm}^{-3} \mathrm{~K}^{+} ; 5.9 \mathrm{cmol}_{\mathrm{c}} \mathrm{dm}^{-3} \mathrm{Ca}^{2+} ; 1.6$ $\mathrm{cmol}_{\mathrm{c}} \mathrm{dm}^{-3} \mathrm{Mg}^{2+} ; 7.9 \mathrm{cmol}_{\mathrm{c}} \mathrm{dm}^{-3}$ sum of bases; $13.5 \mathrm{cmol}_{\mathrm{c}} \mathrm{dm}^{-3} \mathrm{CEC}$ and $58 \% \mathrm{~V}$; and Growing season 2 with $5.2 \mathrm{pH}\left(\mathrm{CaCl}_{2}\right) ; 4.8 \mathrm{mg} \mathrm{dm}^{-3} \mathrm{P}$ (Mehlich-1); $45 \mathrm{~g} \mathrm{~kg}^{-1} \mathrm{OM} ; 0.0 \mathrm{cmolc} \mathrm{dm}^{-3} \mathrm{Al}^{3+}$; $5.7 \mathrm{cmolc} \mathrm{dm}^{-3} \mathrm{H}+\mathrm{Al} ; 0.32 \mathrm{cmol}_{\mathrm{c}} \mathrm{dm}^{-3} \mathrm{~K}^{+} ; 3.7$ $\mathrm{cmol}_{\mathrm{c}} \mathrm{dm}^{-3} \mathrm{Ca}^{2+} ; 1.5 \mathrm{cmol}_{\mathrm{c}} \mathrm{dm}^{-3} \mathrm{Mg}^{2+} ; 5.5 \mathrm{cmol}_{\mathrm{c}}$ $\mathrm{dm}^{-3}$ sum of bases; $11.2 \mathrm{cmol}_{\mathrm{c}} \mathrm{dm}^{-3}$ CEC and $49.5 \%$ V. Based on soil analysis and according to the recommendations for high yields, 32 $\mathrm{kg} \mathrm{ha}^{-1}$ of $\mathrm{N}, 112 \mathrm{~kg} \mathrm{P}_{2} \mathrm{O}_{5} \mathrm{ha}^{-1}$ and $64 \mathrm{~kg} \mathrm{~K}_{2} \mathrm{O}$ $\mathrm{ha}^{-1}$ were applied at sowing of both growing seasons, in the form of $400 \mathrm{~kg} \mathrm{ha}^{-1} \mathrm{~N}-\mathrm{P}-\mathrm{K}$ fertilizer 08-28-16.

The experimental area was desiccated with herbicide glyphosate (33 $\mathrm{g} \mathrm{ae} \mathrm{ha}^{-1}$ ), and insecticide chlorpyrifos was applied (480 g ai ha $\left.{ }^{-1}\right)$. For weed control, atrazine $(1,200$ $\mathrm{g}$ ai $\mathrm{ha}^{-1}$ ) and tembotrione (90 $\mathrm{g}$ ai ha-1) were applied when the crop was at stage V3 (three expanded leaves). The early corn hybrid DKB 240 YG was planted, which has a short plant height and low ear insertion, semi-erect leaves, the maturation characteristics stay green and dry down, lodging resistance and a high stem and root quality. For the summer growing season, planting is recommended at a density between 70,000 and 75,000 plants ha-1. 

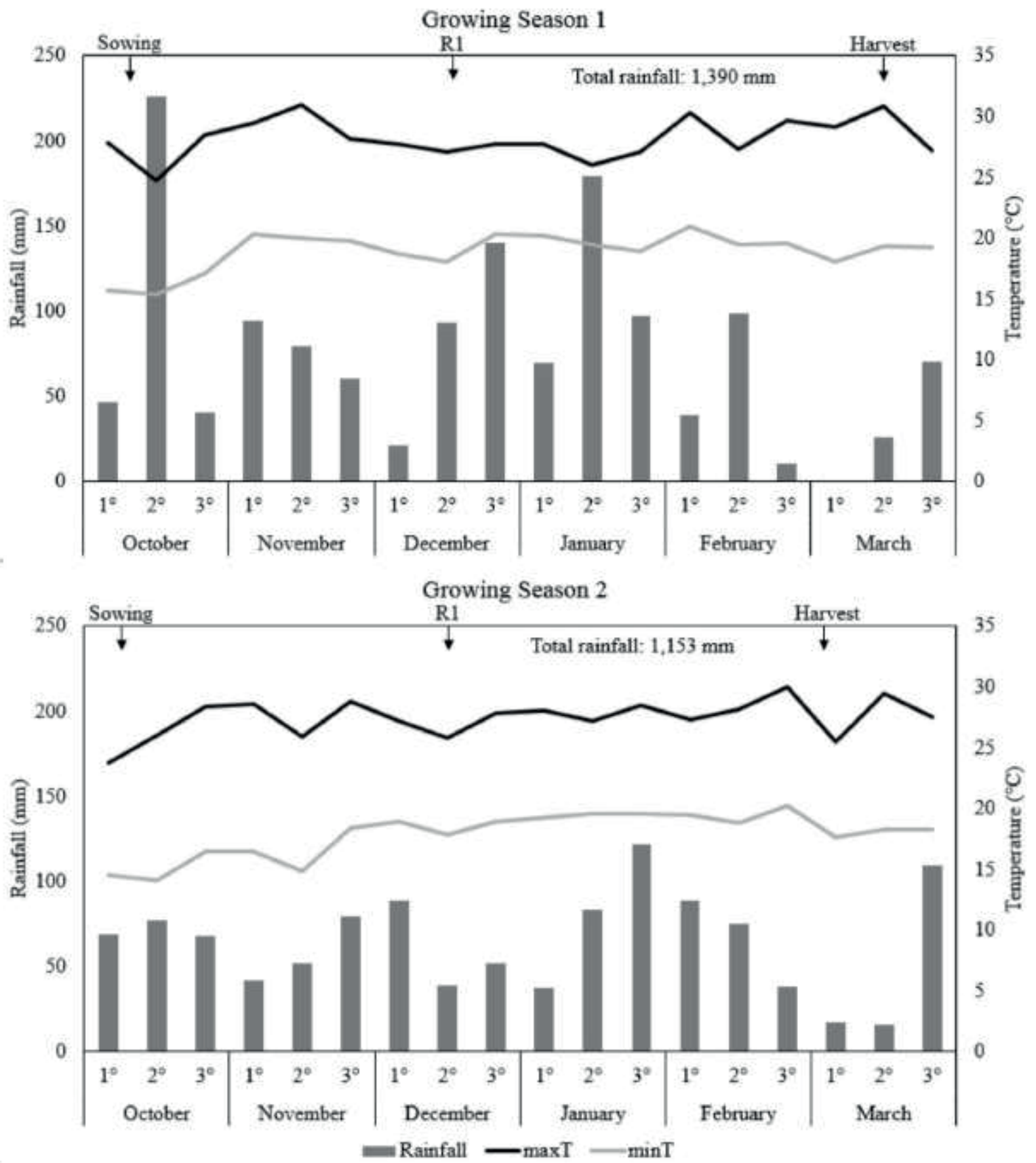

Figure 1. Rainfall $(\mathrm{mm})$, maximum (maxT) and minimum (minT) temperatures, during growing season 1 and 2, from October $1^{\text {st }}$ to March $31^{\text {st }}$, considering the data from the weather station located Marilândia do Sul, Paraná state, Brazil. Total rainfall from corn sowing to harvest: growing season 1 - 1,390 $\mathrm{mm}$; growing season $2-1,153 \mathrm{~mm}$. 
The uninoculated corn seeds were fungicide-treated $(0.0375 \mathrm{~g}$ ai fludioxonil + $0.015 \mathrm{~g}$ ai metalaxyl-m) per $\mathrm{kg}^{-1}$ seed, and insecticide-treated $(52.5 \mathrm{~g}$ ai imidacloprid + $157.5 \mathrm{~g}$ ai thiodicarb) for 60,000 seeds. Furrows were drawn with a fertilizer-seeder, to deposit the fertilizer and outline the rows. Subsequently, two seeds per hole were sown with a seed drill, on October 12 (growing season 1) and October 8 of the following year (growing season 2). The seedlings were thinned to only one plant per hole at stage V2 (two expanded leaves). Nitrogen topdressing was applied on the soil surface at stage V4 (four expanded leaves).

Six random, physiologically mature plants were cut in the evaluation area of the experimental unit, to assess the following phytometric characteristics: stem diameter (measured at the first internode from the plant collar); height of ear insertion (distance from plant collar to point of insertion of the main ear in the stem); plant height (distance from plant collar to the base of the blade of the last leaf). At harvest maturity (22\% grain moisture), the corn of the two central rows of the experimental unit was harvested by hand. Grain weight and moisture were determined after threshing, the moisture content was corrected to $13 \%$ and grain yield was expressed in $\mathrm{kg} \mathrm{ha}^{-1}$.

After checking the assumptions of analysis of variance, the data were subjected to ANOVA and regression analysis ( $p<0.05$ ), using the statistical program Sisvar (D. F. Ferreira, 2011).

\section{Results and Discussion}

In both growing seasons, rainfall (Figure 1) exceeded the historical average of 1,130 mm (Instituto Agronômico do Paraná [IAPAR], 2020). The air temperature ranged from 14 to $31^{\circ} \mathrm{C}$. The water and temperature conditions allowed an adequate development for high corn yields (Maldaner et al., 2014). In growing season 2, the interaction between plant density and $\mathrm{N}$ topdressing rates influenced stem diameter, plant height, ear insertion height and grain yield significantly. In the first growing season, plant height was influenced by the $\mathrm{N}$ rates only. The other evaluated characteristics were influenced by the isolated effects of plant density and $\mathrm{N}$ topdressing rates.

The increase in plant density from 60,000 to 105,000 plants ha $^{-1}$ reduced the stem diameter in both growing seasons linearly (Figure 2A and $2 \mathrm{C}$ ). In growing season 1 , this reduction occurred regardless of the applied $\mathrm{N}$ rates. In growing season 2, when no $\mathrm{N}$ was topdressed (control), the increase from 60,000 to 105,000 plants ha-1 reduced the stem diameter by $21 \%$, but when nitrogen was applied at the lowest rate $\left(60 \mathrm{~kg} \mathrm{ha}^{-1}\right)$, the reduction was $19 \%$ and decreased to $7 \%$ in response to $240 \mathrm{~kg} \mathrm{ha}^{-1}$ of $\mathrm{N}$.

This result confirms findings that an increased population density leads to a reduction in stem diameter (Brachtvogel, Pereira, Cruz, Abreu, \& Bicudo, 2012; Balem et al., 2014; J. P. Ferreira et al., 2015; Sangoi et al., 2019), although these studies did not test the effect of $\mathrm{N}$ fertilization rates. In our study, the angular coefficients of the equations showed that as the $\mathrm{N}$ rates increased, the reduction in stem diameter (angulation of the equations) decreased (Figure 2C). In other words, the lower the applied $\mathrm{N}$ rate, the stronger is the reduction in stem diameter caused by the higher plant density, suggesting that nitrogen has the capacity of mitigating the negative effect of higher plant density on the stem. 
In growing season 1, the increase in $\mathrm{N}$ topdressing rates from 0 to $240 \mathrm{~kg} \mathrm{ha}^{-1}$ caused a linear increase in stem diameter and a quadratic response to all $\mathrm{N}$ rates in growing season 2 (Figure 2B and 2D). In growing season 2 , the higher the corn plant density, the smaller the stem diameter. With the increasing $\mathrm{N}$ rates at each corn density, the stem diameter increased up to a maximum point, above which the applied $\mathrm{N}$ rates began to reduce it. Thus, the thickest diameter (30.72 $\mathrm{mm}$ ) was obtained at the lowest plant density $\left(60,000\right.$ plants $\left.\mathrm{ha}^{-1}\right)$ and a topdressing of 165 $\mathrm{kg} \mathrm{ha}^{-1}$ of $\mathrm{N}$.

\section{GROWING SEASON 1}
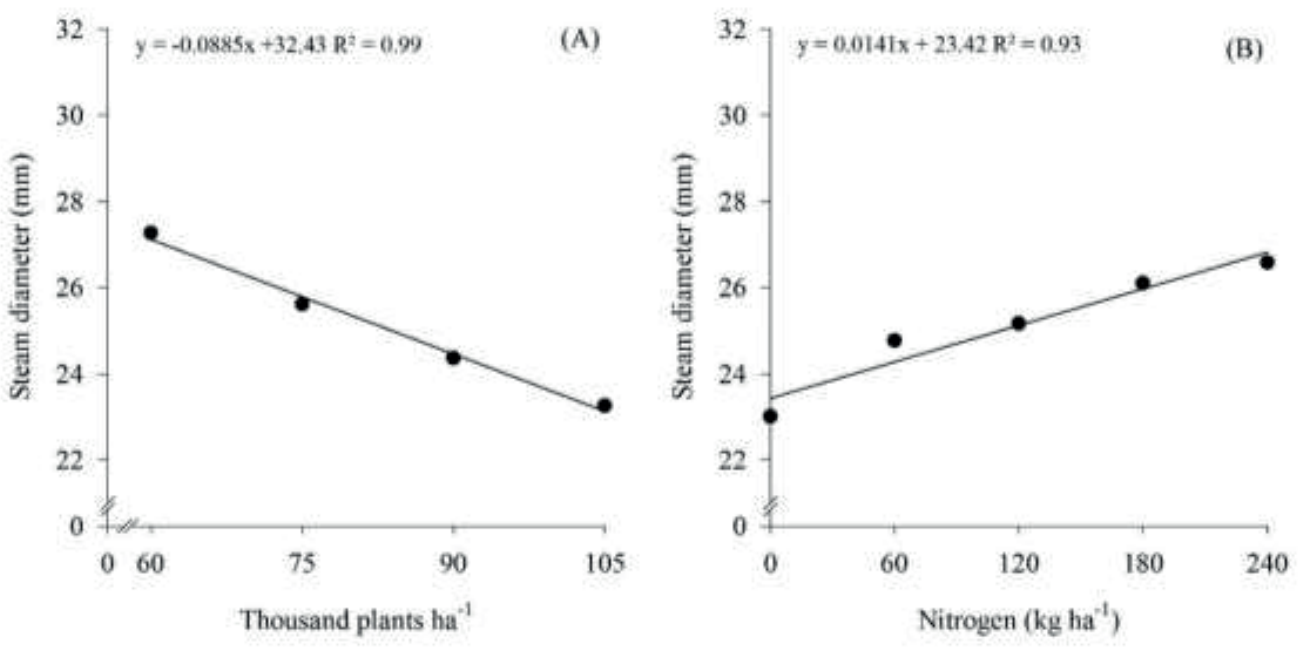

GROWING SEASON 2
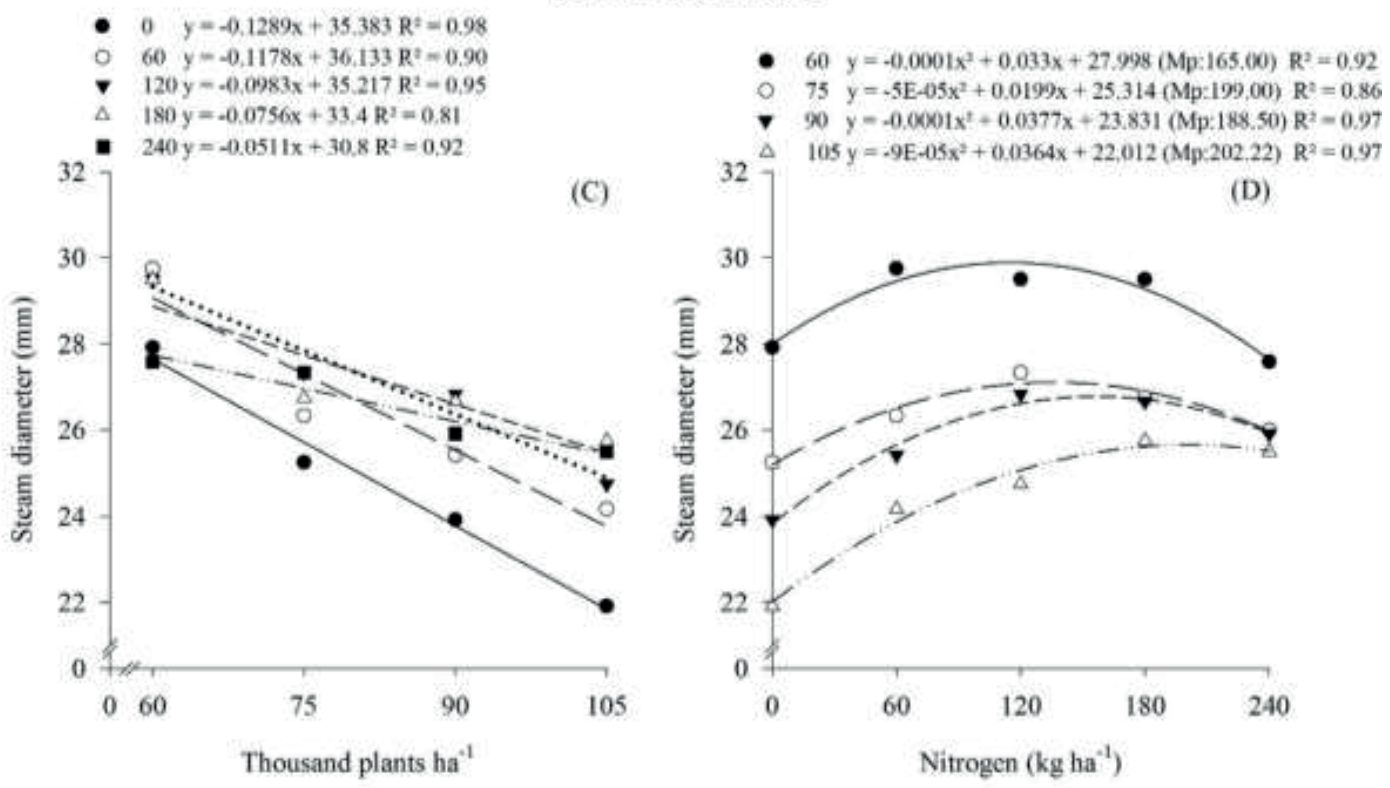

Figure 2. Effect of plant density levels $\left(60,000 ; 75,000 ; 90,000\right.$ and 105,000 plants ha $\left.{ }^{-1}\right)$ and/or nitrogen topdressing rates $\left(0,60,120,180\right.$ and $\left.240 \mathrm{~kg} \mathrm{ha}^{-1}\right)$ on corn, regarding steam diameter, during growing season $1(A$ and $B$ ) and 2 ( $C$ and $D)$. Mp: maximum point. 
Thinner and longer stalks are formed at higher plant densities, as a result of the intensified intraspecific competition for light (Khan et al., 2017). Under this condition, plants invest more resources in elongation in an attempt to outgrow the crop canopy to escape shading and consequently have a reduced stem diameter (Taiz \& Zeiger, 2017). In this situation, $\mathrm{N}$ supply can improve the stem quality and decrease etiolation caused by higher plant densities, although only up to a certain point (Shi et al., 2016), as observed in growing season 2 (Figure 2D).

According to Kappes et al. (2011), stem diameter is positively correlated with yield, considering the same plant density, since thicker stems have a greater capacity of storing photoassimilates for grain filling. In addition, plants with thicker stems are generally more tolerant to lodging and breaking, which is an important trait to obtain the maximal production potential of a crop. No problems with lodging and breaking were detected in this study, not even at 105,000 plants ha $^{-1}$, when the plant stems were thinnest.

In growing season 1, plant height was not affected by density alone or by the interaction density $\times \mathrm{N}$ rates. In growing season 2 , a quadratic response in $\mathrm{N}$ rates to increasing densities was observed in response to $\mathrm{N}$ topdressing rates of 0,60 and $240 \mathrm{~kg}$ ha $^{-1}$ (Figure 3B), resulting in maximum points of $84,130,89,540$ and 89,180 plants ha $^{-1}$, respectively, with plant heights of 231, 233 and $234 \mathrm{~cm}$. According to Brachtvogel et al. (2012), the influence of different plant populations (60,000; 75,000; 90,000 and 105,000 plants ha $^{-1}$ ) on corn morphology and yield also had a quadratic effect on plant height; the tallest plant height $(212 \mathrm{~cm})$ was observed at a population density of 100,000 plants ha $^{-1}$, in response to $24 \mathrm{~kg} \mathrm{~N} \mathrm{ha}^{-1}$ applied at sowing and a topdressing of $120 \mathrm{~kg} \mathrm{ha}^{-1}$ of $\mathrm{N}$.

In growing season 1, there was a quadratic response in plant height to $\mathrm{N}$ rates, regardless of the plant density, resulting in a maximum estimated height of $219.86 \mathrm{~cm}$ at $207.50 \mathrm{~kg} \mathrm{ha}^{-1}$ of $\mathrm{N}$ (Figure 3A). In growing season 2, the partitioning of the interaction at densities of 60,$000 ; 75,000$ and 105,000 plants ha-1 showed maximum points of 180.66 $\mathrm{kg} \mathrm{ha-1}$ of $\mathrm{N}(231.97 \mathrm{~cm}), 169.25$ (234.59 $\mathrm{cm})$ and $151.50 \mathrm{~kg} \mathrm{ha}^{-1}$ of $\mathrm{N}(233.63 \mathrm{~cm})$, respectively (Figure $3 \mathrm{C}$ ). In a study on the interaction between corn populations $(65,000$; 80,000 and 95,000 plants $\left.h^{-1}\right)$ and $\mathrm{N}$ rates $(0$, $120,150,180$ and $210 \mathrm{~kg} \mathrm{ha}^{-1}$ ) to obtain higher corn yields, Imran et al. (2015) found that the $\mathrm{N}$ rates and plant density had separate effects on plant height. In this study, the highest plant density $\left(95,000\right.$ plants ha $\left.^{-1}\right)$ produced the tallest plants $(197 \mathrm{~cm})$, while plants were shortest at the lowest density $(65,000$ plants $\left.\mathrm{ha}^{-1}\right)$. Nitrogen topdressing at $210 \mathrm{~kg} \mathrm{ha}^{-1}$ resulted in taller plants $(202 \mathrm{~cm})$, which was statistically equal to the plant height observed in response to applications of 180 and $150 \mathrm{~kg}$ $\mathrm{ha}^{-1}$ of $\mathrm{N}$ (201 and $198 \mathrm{~cm}$, respectively). The shortest plant height $(181 \mathrm{~cm})$ was recorded in the control plots.

Plant height increases with increasing $\mathrm{N}$ fertilization because the element benefits the vegetative development due to its influence on cell division and expansion and on the photosynthetic process (Biswas; Ma, 2016). In addition, the increase in the amount of applied $\mathrm{N}$ extends the period of vegetative growth, production and accumulation of photoassimilates, resulting in taller plants. The vegetative growth period is also extended when plant density is increased (Imran et al., 2015; Khan et al., 2017). In an evaluation of the effects of corn plant density $(55,000 ; 66,000$ and 83,000 plants $h^{-1}$ ) and $N$ topdressing 
rates $\left(0,50,100,150\right.$ and $\left.200 \mathrm{~kg} \mathrm{ha}^{-1}\right)$ on the agronomic performance of corn, Shrestha, Yadav, Amgain and Sharma (2018) found that the interaction of these factors influences not only the duration of the vegetative period, but also the period until physiological maturity of the crop. The number of days until physiological maturity was highest (135 days) in the combination of $200 \mathrm{~kg} \mathrm{ha}^{-1}$ of $\mathrm{N}$ with a stand of 83,000 plants ha-1 and shortest (130 days) at $0 \mathrm{~kg} \mathrm{ha}^{-1}$ of $\mathrm{N}$ and 55,000 plants ha ${ }^{-1}$. While the highest $\mathrm{N}$ leaf content caused a delay in leaf drying and a consequent increase in the period of production and translocation of photoassimilates, higher plant densities increased plant height, possibly due to the increased competition between plants for solar radiation.

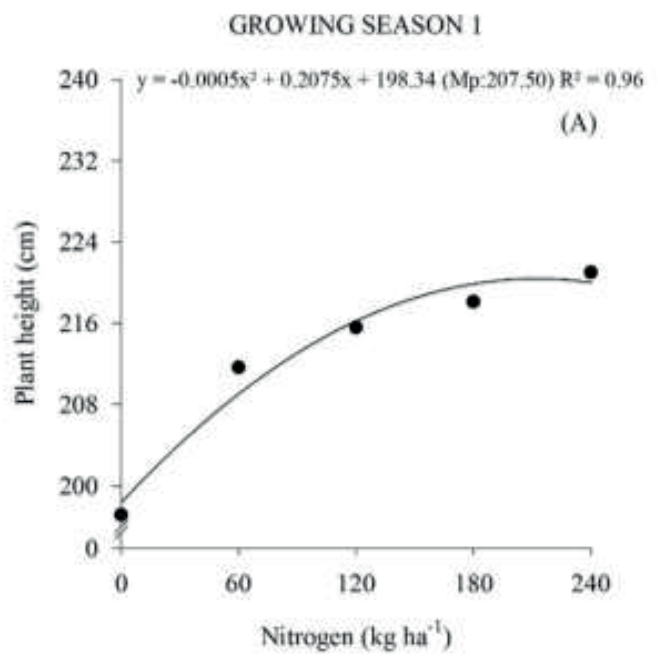

GROWING SEASON 2

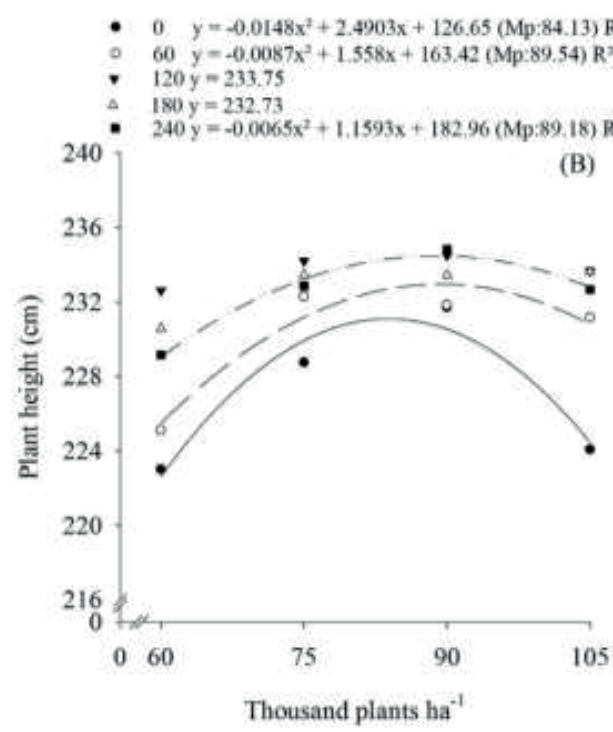

- (6) $y=-0,0003 x^{2}+0,1084 x+222,18(M p ; 180,66) R^{2}=0,81$

$75 y=-0.0002 x^{2}+0.0677 x+228.87(M p: 169.25) R^{2}=0.96$

\% $90, y=233,11$

$=0.98 \quad \Delta \quad 105 y=-0.0004 x^{2}+0.1212 x+224.45(\mathrm{Mp}: 151.50) \mathbf{R}^{2}=0.97$

8) $R^{2}=0.98$

(C)

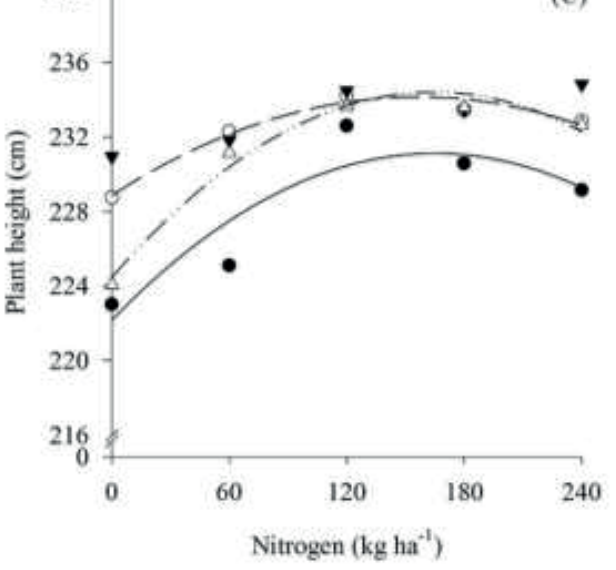

Figure 3. Effect of plant density levels $\left(60,000 ; 75,000 ; 90,000\right.$ and 105,000 plants ha $\left.{ }^{-1}\right)$ and/or nitrogen topdressing rates $\left(0,60,120,180\right.$ and $\left.240 \mathrm{~kg} \mathrm{ha}^{-1}\right)$ on corn, regarding plant height, during growing season 1 ( $A$ and $B$ ) and 2 ( $C$ and $D)$. Mp: maximum point. 
In growing season 1, the increase in plant density linearly increased the ear insertion height, regardless of the $\mathrm{N}$ rate (Figure 4A) and in growing season 2, it promoted a quadratic adjustment in the absence of $\mathrm{N}$ topdressing (Figure $4 \mathrm{C}$ ), resulting in a maximum ear insertion height of 123.15 $\mathrm{cm}$ at a density of 88,660 plants ha- 1 . The increase in $\mathrm{N}$ topdressing rates alone resulted in a quadratic increase in ear insertion height in growing season 1 (Figure 4B). In growing season 2, at 60,000 plants ha-1 (Figure 4D), a quadratic increase was observed, where the highest ear insertion $(126.2 \mathrm{~cm}$ ) was reached with a rate of $168.3 \mathrm{~kg} \mathrm{ha-1}$ of $\mathrm{N}$. According to Farinelli, Penariol and Fornasieri (2012), plants with higher ear insertion height and plant height may be more susceptible to lodging and breaking. A lower ear insertion height increases the stability to maintain the balance of the center of gravity of the plant (Sangoi, 2001), especially when the stem elongates and the diameter decreases in response to the treatments. Possibly, the characteristics of low plant height and ear insertion, the stay green trait and the high quality of stem and roots reinforced the resistance to lodging and breaking of hybrid DKB 240 YG.

GROWING SEASON I
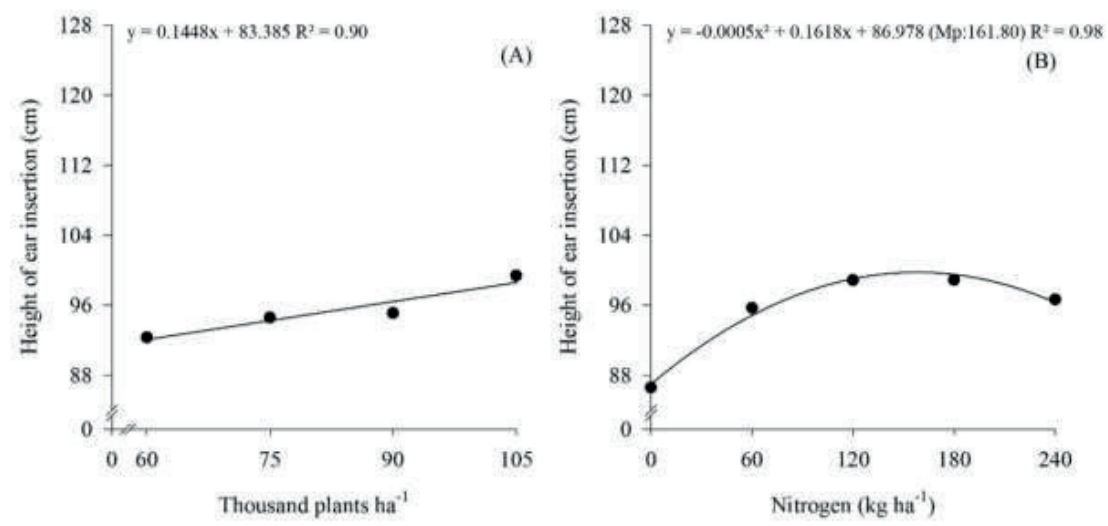

GROWING SEASON 2
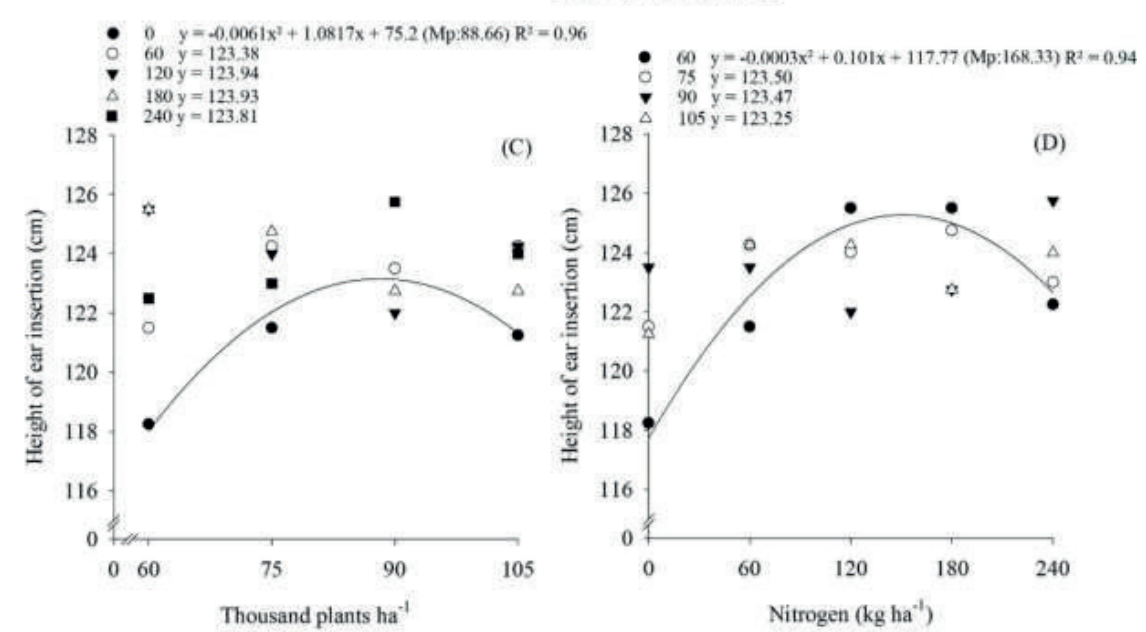

Figure 4. Effect of plant density levels (60,000; 75,000; 90,000 and 105,000 plants ha-1) and/ or nitrogen topdressing rates $\left(0,60,120,180\right.$ and $\left.240 \mathrm{~kg} \mathrm{ha}^{-1}\right)$ on corn, regarding height of ear insertion, during growing season 1 ( $A$ and $B$ ) and 2 ( $C$ and $D)$. Mp: maximum point. 
According to Lana, Rampim, Ohland and Fávero (2014), the effect on ear insertion height of different row spacings, population densities and nitrogen topdressing rates also had a linear response to $\mathrm{N}$ rates at the lowest population density $(60,000$ plants ha- 1$)$ and a quadratic response at the highest density $\left(80,000\right.$ plants $\left.\mathrm{ha}^{-1}\right)$, with a maximum point at the rate of $133.3 \mathrm{~kg} \mathrm{ha}^{-1}$ of $\mathrm{N}$. These authors added that the observed reduction in ear insertion height due to $\mathrm{N}$ rates according to a quadratic function may be related to the higher demand for other nutrients, which become limiting due to the taller plant height as a result of the greater $\mathrm{N}$ input and higher plant density. On the other hand, it is important to remember that high $\mathrm{N}$ concentrations can have a negative effect on plants (Zeleke, Alemayehu, \& Yihenew, 2018).

In growing season 1, the isolated increase in plant density increased grain yield linearly (Figure 5A), from $10.7 \mathrm{Mg} \mathrm{ha}^{-1}$ at 60,000 plants ha-1 to $12.5 \mathrm{Mg} \mathrm{ha}^{-1}$ at 105,000 plants $\mathrm{ha}^{-1}$. In growing season 2, the densities influenced grain yield (Figure $5 \mathrm{C}$ ), inducing linear increases $\left(0,60,120\right.$ and $\left.180 \mathrm{~kg} \mathrm{~N} \mathrm{ha}^{-1}\right)$ and a quadratic response to $240 \mathrm{~kg} \mathrm{ha}^{-1}$ of $\mathrm{N}$, where a grain yield of $15.4 \mathrm{Mg} \mathrm{ha}^{-1}$ was calculated at a maximum point of 105,000 plants ha-1. Only at $240 \mathrm{~kg} \mathrm{ha}^{-1}$ of $\mathrm{N}$ an optimum density of 125,000 plants ha-1 could be estimated with a maximum calculated grain yield of $15.7 \mathrm{Mg} \mathrm{ha}^{-1}$. In contrast, grain yield was lowest $(11.0 \mathrm{Mg}$ ha$\left.{ }^{1}\right)$ at 60,000 plants $\mathrm{ha}^{-1}$, when no $\mathrm{N}$ topdressing was applied ( $\left.0 \mathrm{~kg} \mathrm{ha}^{-1}\right)$ (Figure $\left.5 \mathrm{C}\right)$. The absence of $\mathrm{N}$ supply was also the treatment in which the estimated increase in grain yield was lowest in response to increasing plant densities $(347 \mathrm{~kg}$ $\mathrm{ha}^{-1}$ for every additional 15,000 plants ha ${ }^{-1}$ ) while the application of $180 \mathrm{~kg} \mathrm{ha}^{-1}$ of $\mathrm{N}$ resulted in a grain yield increase of $866 \mathrm{~kg} \mathrm{ha}^{-1}$ for every additional 15,000 plants ha-1.

In a study on the effect of plant density and $\mathrm{N}$ rates on corn, Yan et al. (2017) observed the influence of the interaction of both factors in two years of evaluation. As the plant density increased from 60,000 to 75,000 plants ha $^{-1}$, the maximum calculated grain yield increased from 11.3 to $12.4 \mathrm{Mg} \mathrm{ha}^{-1}$, and the $\mathrm{N}$ rate required to achieve this yield increased from 131 to $150 \mathrm{~kg} \mathrm{ha}^{-1}$ of $\mathrm{N}$. The lower density $\left(60,000\right.$ plants $\left.\mathrm{m}^{-1}\right)$ decreased the biomass and cumulative $\mathrm{N}$ in corn plants due to a low leaf area index, resulting in low grain yield. This result indicated that an adequate density combined with an optimized $\mathrm{N}$ fertilization management to meet the higher demand of densely planted corn increases the grain yield, as observed in this research.

In growing season 1, yield was adjusted to the increasing linear function when the $\mathrm{N}$ rates were increased independent from plant density (Figure 5B). The maximum point in response to $240 \mathrm{~kg} \mathrm{ha}^{-1}$ of $\mathrm{N}$ resulted in a grain yield of $12.9 \mathrm{Mg} \mathrm{ha}^{-1}$, which is $13 \%$ higher than in the treatment without $\mathrm{N}$ topdressing. This result agrees with that of Kappes, Arf, Dal Bem, Portugal and Gonzaga (2014), who evaluated the influence of nitrogen sources, application times and topdressing rates on no-tillage corn and also observed a positive effect of $\mathrm{N}$ on corn yield. The application of $150 \mathrm{~kg} \mathrm{ha}^{-1}$ of $\mathrm{N}$ resulted in a grain yield of $10.0 \mathrm{Mg} \mathrm{ha}^{-1}$, i.e., an increase of $15.5 \%$ compared to the treatment without $\mathrm{N}$. These effects indicate the importance of $\mathrm{N}$ fertilization to supply the crop demand, preventing limitations in plant growth and development and raising grain yields, especially in summer conditions, favorable to corn. 
This relevance was also observed in growing season 2 , in which the increasing $\mathrm{N}$ topdressing rates influenced grain yield at all population densities $(60,000 ; 75,000 ; 90,000$ and 105,000 plants ha $\left.^{-1}\right)$, with quadratic responses (Figure 5D). The higher the density, the higher the yield and for each density, the appropriate $\mathrm{N}$ rate could be determined. Thus, the maximum yield (15.6 $\mathrm{Mg} \mathrm{ha}^{-1}$ ) was obtained in response to a topdressing of $185 \mathrm{~kg} \mathrm{ha}^{-1}$ of $\mathrm{N}$ at 105,000 plants ha-1. On the other hand, grain yield was lowest (12.8 $\mathrm{Mg} \mathrm{ha}^{-1}$ ) at 60,000 plants ha-1 and a topdressing of $162 \mathrm{~kg} \mathrm{ha}^{-1}$ of $\mathrm{N}$, i.e., a reduction of $18 \%$.

\section{GROWING SEASON 1}
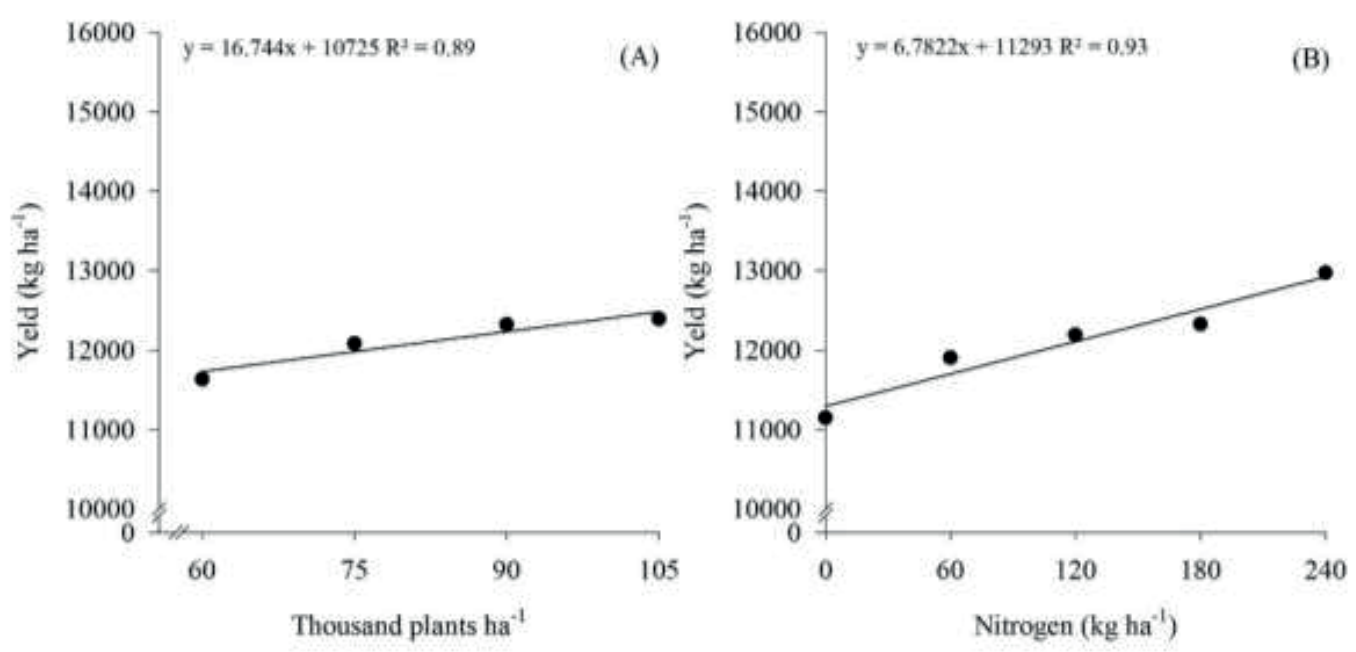

GROWING SEASON 2
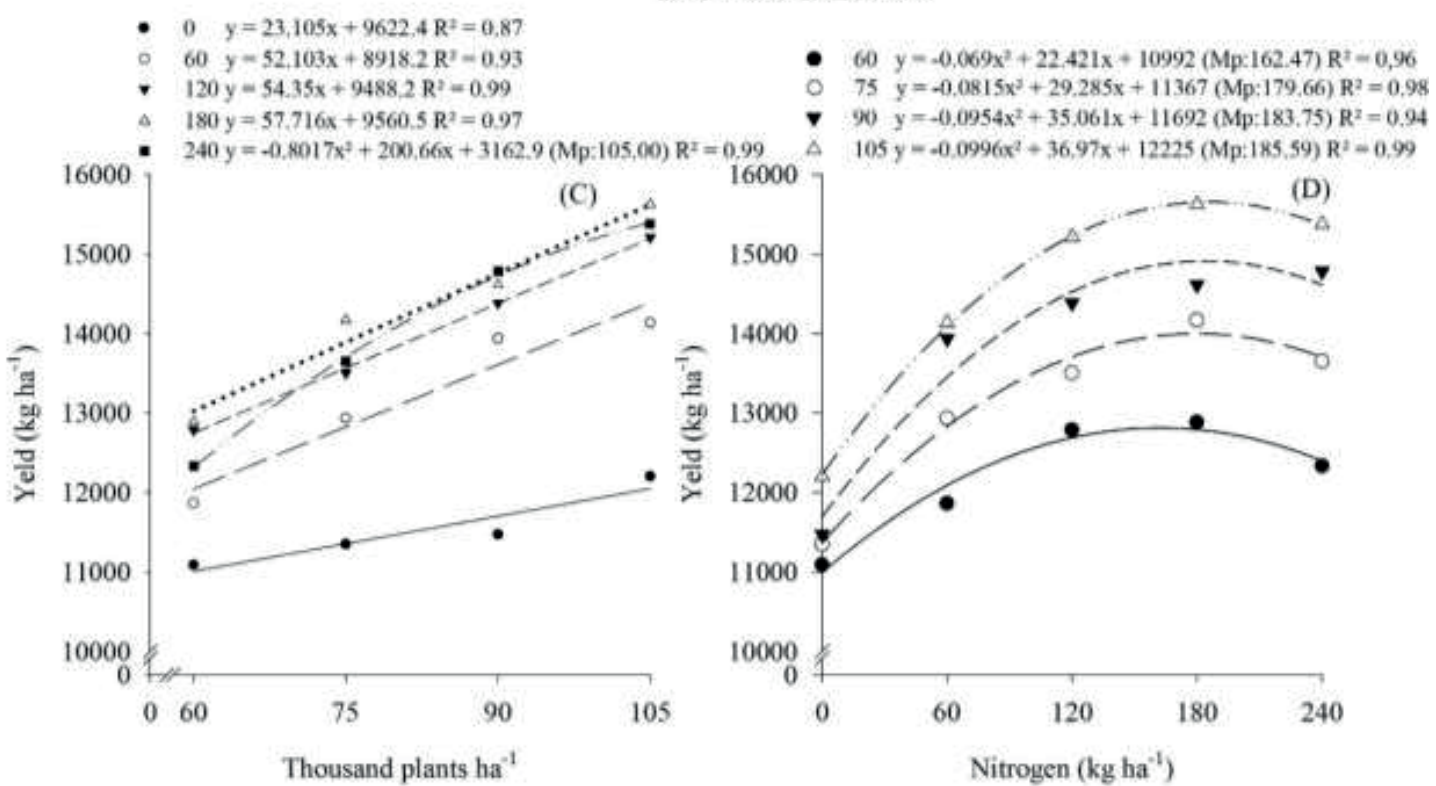

Figure 5. Effect of plant density levels (60,000; 75,000; 90,000 and 105,000 plants ha $\left.^{-1}\right)$ and/or nitrogen topdressing rates $\left(0,60,120,180\right.$ and $\left.240 \mathrm{~kg} \mathrm{ha}^{-1}\right)$ on corn, regarding grain yield, during growing season 1 ( $A$ and $B$ ) and 2 ( $C$ and $D)$. Mp: maximum point. 
Similarly, in a study of $\mathrm{N}$ rates and three plant densities at a $0.75-\mathrm{m}$ row spacing, Zeleke et al. (2018) found a $42 \%$ higher grain increase between the maximum yield obtained with the combination of 88,000 plants $\mathrm{ha}^{-1}$ and $161 \mathrm{~kg} \mathrm{ha}^{-1}$ of $\mathrm{N}$ (12.4 $\left.\mathrm{Mg} \mathrm{ha}^{-1}\right)$, as opposed to the minimum, with the association of 44,000 plants ha-1 and $161 \mathrm{~kg} \mathrm{ha}^{-1}$ of $\mathrm{N}\left(7.0 \mathrm{Mg} \mathrm{ha}^{-1}\right)$. According to the authors, a high plant density and adequate nitrogen supply are beneficial for corn when all other conditions are favorable to achieve the highest grain yield. Thus, the increase in plant density to optimize the use of environmental resources requires an increased $\mathrm{N}$ supply to avoid a reduction in corn yield.

The responses of stem diameter, plant height, ear insertion height and corn yield to the increase in plant density and $\mathrm{N}$ rates were influenced by the conditions of the production environment, since in growing season 1 no interaction effect was detected but in growing season 2 it influenced the results. Water, light, radiation and nutrient availability mainly determine the appropriate density to obtain highest yields (Schwalbert et al., 2018). When these resources are provided at satisfactory levels, the limiting factor may be related to the genetic potential of the cultivar and not to environmental factors (Assefa et al., 2016). In our experiment, despite the adequate water and thermal availability for corn growth and development in both growing seasons, another environmental factor may probably have prevented the interaction effect of factors on the crop in growing season 1, as proven by the lower maximum yield in growing season 1 (12.9 $\mathrm{Mg} \mathrm{ha}^{-1}$ ) compared to growing season 2 (15.6 $\mathrm{Mg} \mathrm{ha}^{-1}$ ) of the same cultivar DKB 240 YG.
In this study, a maximum corn grain yield of $15.6 \mathrm{Mg} \mathrm{ha}^{-1}$ was achieved in a stand of 105,000 plants ha-1 and with a topdressing of $185 \mathrm{~kg} \mathrm{ha}^{-1}$ of $\mathrm{N}$. It is noteworthy that even in the treatment without nitrogen topdressing, the grain yield exceeded $10.9 \mathrm{Mg} \mathrm{ha}^{-1}$ in both growing seasons. This response can be ascribed to the $\mathrm{N}$ fertilizer applied at sowing (32 $\mathrm{kg} \mathrm{N} \mathrm{ha}^{-1}$ ), the decomposition of available organic matter in the soil $\left(38 \mathrm{~g} \mathrm{~kg}^{-1}\right.$ and $45 \mathrm{~g}$ $\mathrm{kg}^{-1} \mathrm{OM}$, respectively, in growing season 1 and 2) and/or the decomposition of the residues of the previous crop, as stated by Kappes, Silva and Ferreira (2017).

In a review of 100 studies involving plant density and $\mathrm{N}$ rates, Ciampitti and Vyn (2012) found that as the plant density increases, $N$ absorption increases per area unit. According to Tajul et al. (2013), in an evaluation of the effects of plant density $(53,000,66,000$ and 80,000 plants ha $^{-1}$ ) and $N$ topdressing (100, 140, 180 and $220 \mathrm{~kg} \mathrm{ha}^{-1}$ ) on corn yield and components, the increase in plant density from 53,000 to 80,000 plants ha $^{-1}$ increased the $\mathrm{N}$ demand from 100 to $180 \mathrm{~kg} \mathrm{ha}^{-1} \mathrm{of} \mathrm{N}$. It also increased the leaf area index of the corn plants, which allowed a greater absorption of solar radiation and improved growth efficiency, resulting in higher grain yields.

Modern cultivars are more responsive to increases in plant density and $\mathrm{N}$ fertilization because the plants can use resources more efficiently and tolerate higher densities, allowing the full expression of the yield potential of a cultivar (Ciampitti \& Vyn, 2011; Yan et al., 2017). Environmental resources influence both plant density and nitrogen use efficiency (Dhital \& Raun, 2016; Schwalbert et al., 2018). Thus, factors such as cultivar and edaphoclimatic conditions may explain the divergences between the responses in grain 
yield when combining higher plant densities with increased nitrogen topdressing rates, reinforcing the need for less generalized recommendations for the exploration of the full yield potential of corn.

\section{Conclusions}

The stem diameter, plant height, ear insertion height and grain yield were influenced by the interaction between plant density and nitrogen topdressing under the tested highaltitude edaphoclimatic conditions.

The stem diameter of corn plants decreased due to the increase in plant density whereas nitrogen topdressing attenuated this reduction Maximum plant height was observed at a density of 75,000 plants ha $^{-1}$ associated with a topdressing of $169 \mathrm{~kg} \mathrm{ha}^{-1}$ of $\mathrm{N}$, and highest ear insertion at 60,000 plants ha-1 and $168 \mathrm{~kg} \mathrm{ha}^{-1}$ of N. Corn yield was highest at a density of 105,000 plants ha-1 associated with a topdressing of $185 \mathrm{~kg} \mathrm{ha}^{-1}$ of $\mathrm{N}$.

\section{Acknowledgments}

This study was carried out with the support of the Coordenação de Aperfeiçoamento de Pessoal de Nível Superior (Capes - Brazil - Financing code 001).

\section{References}

Abuzar, M.R.,Sadozai, G.U.,Baloch, M.S.,Baloch, A. A., Shah, I. H., Javaid, T., \& Hussain, N. (2011). Effect of plant population densities on yield of maize. The Journal of Animal \& Plant Sciences, 21(4), 692-695. doi: 10.1080/01448765.1993.9754659
Al-Naggar, A. M. M., Shabana, R. A., Atta, M. M., \& Al-Khalil, T. H. (2015). Maize response to elevated plant density combined with lowered $\mathrm{N}$-fertilizer rate is genotypedependent. The Crop Journal, 3(2), 96109. doi: 10.1016/j.cj.2015.01.002

Assefa, Y., Prasad, P. V., Carter, P., Hinds, M., Bhalla, G., Schon, R.,... Ciampitti, I. A. (2016). Yield responses to planting density for US modern corn hybrids: A synthesisanalysis. Crop Science, 56(5), 2802-2817. doi: 10.2135/cropsci2016.04.0215

Balem, Z., Modolo, A. J., Trezzi, M. M., Vargas, T. D. O., Baesso, M. M., Brandelero, E. M., \& Trogello, E. (2014). Conventional and twin row spacing in different population densities for maize (Zea mays L.). African Journal of Agricultural Research, 9(23), 1787-1792. doi: 10.5897/AJAR2014.8714

Biswas, D. K., \& Ma, B. L. (2016). Effect of nitrogen rate and fertilizer nitrogen source on physiology, yield, grain quality, and nitrogen use efficiency in corn. Canadian Journal of Plant Science, 96(3), 392-403. doi: 10.1139/cjps-2015-0186

Brachtvogel, E. L., Pereira, F. R. D. S., Cruz, S. C. D. S., Abreu, M. L. D., \& Bicudo, S. J. (2012). População, arranjo de plantas uniforme e a competição intraespecífica em milho. Revista Trópica: Ciências Agrárias e Biológicas, 6(1), 75-83. doi: 10.0000/rtcab. v6i1.582

Ciampitti, I. A., \& Vyn, T. J. (2011). A comprehensive study of plant density consequences on nitrogen uptake dynamics of maize plants from vegetative to reproductive stages. Field Crops Research, 121(1), 2-18. doi: 10.1016/j.fcr. 2010.10.009 
Ciampitti, I. A., \& Vyn, T. J. (2012). Physiological perspectives of changes over time in maize yield dependency on nitrogen uptake and associated nitrogen efficiencies: a review. Field Crops Research, 133(1), 48-67. doi: 10.1016/j.fcr.2012.03.008

Cruz, J. C., Garcia, J. C., Pereira, I. A., Fo., Pinto, L., \& Queiroz, L. (2009). Caracterização dos sistemas de produção de milho para altas produtividades. Sete Lagoas: EMBRAPA Milho e Sorgo-Circular Técnica.

Dhital, S., \& Raun, W. R. (2016). Variability in optimum nitrogen rates for maize. Agronomy Journal, 108(6), 2165-2173. doi: 10.2134/agronj2016.03.0139

Farinelli, R., Penariol, F. G., \& Fornasieri, D., Fo. (2012). Características agronômicas e produtividade de cultivares de milho em diferentes espaçamentos entre linhas e densidades populacionais. Científica, 40(1), 21-27. doi: 10.15361/1984-5529.2012v40 n1p21+-+27

Ferreira, D. F. (2011). Sisvar: a computer statistical analysis system. Ciência e Agrotecnologia, 35(6), 1039-1042. doi: 10.1590/S1413-70542011000600001

Ferreira, J. P., Rodrigues, R. A. F., Kaneko, F. H., Kappes, C., Arf, M. V., \& Goés, R. J. (2015). Características agronômicas do milho sob arranjos espaciais e densidades de plantas em região de cerrado. Cultura Agronômica: Revista de Ciências Agronômicas, 24(1), 27-44. doi: 10.32929/2446-8355.2015v24n1p27-44

Gong, F., Wu, X., Zhang, H., Chen, Y., \& Wang, W. (2015). Making better maize plants for sustainable grain production in a changing climate. Frontiers in Plant Science, 6(1), 835. doi: 10.3389/ fpls.2015.0 0835
Imran, S., Arif, M., Khan, A., Khan, M. A., Shah, W., \& Latif, A. (2015). Effect of nitrogen levels and plant population on yield and yield components of maize. Advances in Crop Science and Technology, 3(2), 1-7. doi: 10.4172/2329-8863.1000170

Instituto Agronômico do Paraná (2020). Médias históricas em estações do IAPAR: Mauá da Serra - PR. Recuperado de http://www. idrparana.pr.gov.br/system/files/publico/ agrometeorologia/medias-historicas/ Maua_da_Serra.pdf

Kappes, C., Andrade, J. A. D. C., Arf, O., Oliveira, A. C. D., Arf, M. V., \& Ferreira, J. P. (2011). Desempenho de híbridos de milho em diferentes arranjos espaciais de plantas. Bragantia, 70(2), 334-343. doi: 10.1590/ S0006-87052011000200012

Kappes, C., Silva, R. D., \& Ferreira, V. E. N. (2017). Aplicação foliar de Azospirillum brasilense e doses de nitrogênio em cobertura no milho safrinha. Scientia Agraria Paranaensis, 16(3), 366-373. doi: 10.1818 8/1983-1471/sap.v16n3p366-373

Kappes, C., Arf, O., Dal Bem, E. A., Portugal, J. R., \& Gonzaga, A. R. (2014). Manejo do nitrogênio em cobertura na cultura do milho em sistema plantio direto. Revista Brasileira de Milho e Sorgo, 13(2), 201217. doi: 10.18512/1980-6477/rbms.v13 n2p201-217

Khan, Z. H., Khalil, S. K., Shah, F., Iqbal, A., Ali, F., Islam, I. B., \& Ali, M. (2017). Plant density and nitrogen doses can affect growth of sweet corn. Fresenius Environmental Bulletin, 26(6), 3872-3879. Recovered from https:// www.researchgate.net/profile/ZafarHayat-4/publication/317615922_PLANT_ DENSITY_AND_NITROGEN_DOSES_CAN_ AFFECT_GROWTH_OF_SWEET_CORN/ 
links/59437f6da6fdccb93ab28a8a/PLANTDENSITY-AND-NITROGEN-DOSES-CANAFFECT-GROWTH-OF-SWEET-CORN.pdf

Lana, M. D. C., Rampim, L., Ohland, T., \& Fávero, F. (2014). Spacing, population density and nitrogen fertilization in corn grown in an Oxisoil. Revista Ceres, 61(3), 424-433. doi: 10.1590/S0034-737X2014000300018

Maldaner, L. J., Horing, K., Schneider, J. F., Frigo, J. P., Azevedo, K. D. de, \& Grzesiuck, A. E. (2014). Exigência agroclimática da cultura do milho. Revista Brasileira de Energias Renováveis, 3(1), 13-23. doi: 10.5380/rber. v3i1.36915

Mendes, M.C., Matchula,P.H., Rossi, E.S., Oliveira, B. R., Silva, C. A., \& Sékula, C. R. (2013). Adubação nitrogenada em cobertura associada com densidades populacionais de híbridos de milho em espaçamento reduzido. Revista Brasileira de Milho e Sorgo, 12(2), 92-101. doi: 10.18512/19806477/rbms.v12n2p92-101

Modolo, A. J., Carnieletto, R., Kolling, E. M., Trogello, E., \& Sgarbossa, M. (2010). Desempenho de híbridos de milho na RegiãoSudoeste do Paraná sob diferentes espaçamentos entre linhas. Revista Ciência Agronômica, 41(3), 435-441. doi: 10.1590/s1806-66902010000300016

Neumann, M., Poczynek, M., Leão, G. F. M., Figueira, D. N., \& Souza, A. M. (2018). Desempenho de híbridos de milho para silagem cultivados em diferentes locais com três densidades populacionais. Revista Brasileira de Milho e Sorgo, 17(1), 49-62. doi: 10.18512/1980-6477/rbms. v17n1p49-62

Pauletti, V., \& Motta, A. C. V. (2019). Manual de adubação e calagem para o estado do
Paraná. Curitiba: Núcleo Estadual Paraná da Sociedade Brasileira de Ciência do Solo.

Sangoi, L. (2001). Understanding plant density effects on maize growth and development: an important issue to maximize grain yield. Ciência Rural, 31(1), 159-168. doi: 10.1590/S0103-84782001000100027

Sangoi, L., Schmitt, A., Durli, M. M., Leolato, L. S., Coelho, A. E., Kuneski, H. F., \& Vander de Liz, O. (2019). Estratégias de manejo do arranjo de plantas visando otimizar a produtividade de grãos do milho. Revista Brasileira de Milho e Sorgo, 18(1), 47-60. doi: 10.18512/1980-6477/rbms.v18n1p47-60

Santos, H. G., Jacomine, P. K. T., Anjos, L. H. C., Oliveira, V. A., Lumbreras, J. F., Coelho, M. R.,... Cunha, T. J. F. (2018). Sistema brasileiro de classificação de solos (5a ed.). Brasília, DF: EMBRAPA.

Schwalbert, R., Amado, T. J., Horbe, T. A., Stefanello, L. O., Assefa, Y., Prasad, P. V.,... Ciampitti, I. A. (2018). Corn yield response to plant density and nitrogen: Spatial models and yield distribution. Agronomy Journal, 110(3), 970-982. doi: 10.2134/ agronj2017.07.0425

Shi, D. Y., Li, Y. H., Zhang, J. W., Liu, P., Zhao, B., \& Dong, S. T. (2016). Effects of plant density and nitrogen rate on lodgingrelated stalk traits of summer maize. Plant Soil and Environment, 62(7), 299-306. doi: 10.17221/720/2015-PSE

Shrestha, J., Yadav, D. N., Amgain, L. P., \& Sharma, J. P. (2018). Effects of nitrogen and plant density on maize (Zea mays L.) phenology and grain yield. Current Agriculture Research Journal, 6(2), 175182. doi: 10.12944/CARJ.6.2.06 
Silva, P. R. F., Piana, A. T., Maass, L. B., Silva Serpa, M. da, Sangoi, L., Vieira, V. M., Endrigo, P. C., \& Jandrey, D. B. (2010). Adequação da densidade de plantas à época de semeadura em milho irrigado. Revista de Ciências Agroveterinárias, 9(1), 48-57. Recovered from https:// www.periodicos.udescbr/index.php/agro veterinaria/article/view/5285/3495

Taiz, L., \& Zeiger, E. (2017). Fisiologia e desenvolvimento vegetal (6a ed.). Porto Alegre: Artmed.

Tajul, M. I., Alam, M. M., Hossain, S. M. M., Naher, K., Rafii, M. Y., \& Latif, M. A. (2013). Influence of plant population and nitrogen-fertilizer at various levels on growth and growth efficiency of maize. The Scientific World Journal, 2013(1), 1-9. doi: $10.1155 / 2013 / 193018$

Tokatlidis, I. S., Has, V., Melidis, V., Has, I., Mylonas, I., Evgenidis, G.,... Fasoula, V. A. (2011). Maize hybrids less dependent on high plant densities improve resourceuse efficiency in rainfed and irrigated conditions. Field Crops Research, 120(3), 345-351. doi: 10.1016/j.fcr.2010.11.006
United States Department of Agriculture (2014). Soil survey staff. Keys to soil taxonomy (12a ed.). Washington, D.C.: USDA.

United States Department of Agriculture (2020). Grain: world markets and trae. Foreign agricultural services. Retrieved from https://apps.fas.usda.gov/psdonline/ circulars/grain-corn-coarsegrains.pdf

Yan, P., Pan, J., Zhang, W., Shi, J., Chen, X., \& Cui, Z. (2017). A high plant density reduces the ability of maize to use soil nitrogen. Plos One, 12(2), e0172717. doi: 10.1371/ journal.pone.0172717

Zeleke, A., Alemayehu, G., \& Yihenew, G. S. (2018). Effects of planting density and nitrogen fertilizer rate on yield and yield related traits of maize (Zea mays, L.) in Northwestern, Ethiopia. Advances in Crop Science Technology, 6(2), 1-5. doi: 10.4172/2329-8863.1000352 
